\title{
ENTREPRENEURIAL CHARACTERISTICS AND CONSTRAINTS OF POULTRY ENTERPRISES IN IMO STATE, NIGERIA
}

\author{
I. C. Okoli, C. N. Anyaegbunam, E. B. Etuk, M. N. Opara, and A. B. I. Udedibie
}

\begin{abstract}
The, entrepreneurial characteristics marketing strategies, poultry drugs distribution methods and constraints were studied among 110 poultry enterprises in Imo State, Nigeria. Ten types of poultry businesses were identified with commercial feeds retailing, egg and broiler productions being the most frequently practiced (18.1, 15.3 and $15.2 \%$ respectively). Guinea and Top feed brands were the most popular commercial poultry feeds, with each rating 28.1 and $23.4 \%$ respectively. Thirtyfive(55.6\%) of poultry farmers use commercial poultry feeds in feeding their flocks. Small-scale commercial poultry farms (40.4\%) were more as against middle and large scale units that averaged 30.8 and $28.9 \%$ respectively. $82.9 \%$ of the poultry farmers sell their products unprocessed either by retails and wholesales (41.9\%), or by retail only (20.9\%). Twenty-three (79.3\%) of poultry drugs sellers in the state are not qualified to sell such drugs, while a higher percentage of the farmers consult veterinary doctors before administering drugs. Antibiotics $(23.9 \%)$, coccidiostats $(23.1 \%)$, vitamins $(17.4 \%)$ and vaccines $(14.1 \%)$ were the most frequently sold poultry medicinal products. Practitioners identified high cost of livestock inputs $(31.3 \%)$, lack of adequate finance (26.6\%) and disease (17.2\%) as major constraints to their business. Researching for cheaper sources of raw materials (30.8\%), visiting farms for advice (23.1\%) and producing animals with higher feed efficiency by animal production scientists and financial support in forms of soft loans, credits and subsidies from government (58.33\%), were listed as the highest expectations of the practitioners.
\end{abstract}

Key words: Nigeria, poultry business, veterinary drugs, poultry feeds, Poultry farmers.

\section{INTRODUCTION}

Intensive poultry production was introduced into Nigeria over fifty years ago and has developed rapidly especially in the last few decades as an important livestock business enterprise in the country (FAO, 2000). . Intensive poultry production involves commercial rearing of high performance exotic breeds of chicken. This system is resource driven and requires the operator to be in control of the housing, nutritional and health needs of the birds (Oluyemi and Roberts, 1979).

Over the last few decades, successive governments have encouraged the development of modern poultry enterprises with a resultant sudden rush of people of diverse backgrounds into the industry. This has resulted in the development of an unplanned and unregulated industry with numerous attendant problems (Okoli, 2004). Commercial poultry production is attractive because birds are able to adapt easily, have high economic value, rapid generation time and a high rate of productivity that can result in the production of meat within eight weeks and first egg within eighteen weeks of the first chick being hatched (Smith, 1990).

There is a continual need therefore to generate information on the facts about poultry business enterprises in Nigeria. Such information is needed for proper planning and regulation of the industry in Nigeria. Available data on the current facts about entrepreneurial characteristics and constraints to robust development of poultry business enterprises in southeastern Nigeria and Imo state in particular are however scanty and fragmented (Okoli et al 2004). The present study was designed to investigate the entrepreneurial characteristics and constraints to poultry business enterprises in Imo state, Nigeria.

\section{METHODOLOGY}

Imo state is situated in the southeastern rainforest vegetation belt of Nigeria and lies 
between latitude $5^{0} 4^{\prime}$ and $6^{0} \quad 3^{\prime} \mathrm{N}$ and longitude $6^{0} \quad 1^{\prime}$ and $7^{0} 34^{\prime} \mathrm{E}$. The agro-ecological characteristics and political distribution of the area have been reported (Okoli, 2004).

The primary data used in the study were generated from a field survey conducted between September 2003 and January 2004 and covered the three senatorial zones of Imo state. The study proper was preceded by preliminary informal survey of the study areas through which the researchers became familiarized with the nature of agro-livestock businesses in the area and explained the purpose of the study to the participants. Data collection methods employed were as previously described by Okoli, et al (2005). Altogether, 120 questionnaires were distributed and at the end, 110 were valid. The data obtained were analyzed using descriptive statistics such as frequency distribution, percentage and tables.

\section{RESULTS AND DISCUSSION}

\section{Types of poultry businesses enterprises}

Table 1 highlighted the types of poultry business enterprises and the frequency at which they are being practiced in the state. Overall, 10 types of poultry business enterprises were identified, with commercial feeds retailing (18.1\%), egg (15.2\%) and broiler (15.2\%) productions being the most frequently practiced by the respondents. The result agrees with the report of Meremikwu (2000) that within the last decade many poultry farms producing broilers and eggs were established in Nigeria. Poultry plays an important role as a fast source of protein-production, comes fourth among major sources of animal protein for human consumption in Nigeria and contributes about $10 \%$ of the national meat production (Adu et al, 1996).

Table $2 \mathrm{a}$ showed that $55.60 \%$ of poultry farmers in the state use commercial poultry feeds in feeding their flocks. This probably is due to lack of knowledge about feed formulation. This is expected since a high proportion of those involved in the business do not have formal agricultural education background (Okoli et al, 2005). Again, the actual size of most of these farms may be too small for the practitioners to go into feed formulation.

Among the commercial poultry feed brands sold in Imo State (table 5b), Guinea, Top and Vital feeds have more retailing outlets, while Vetlink, PMC and Livestock had the least number of outlets. Guinea and Top feeds were again more popular among the poultry feed users (Table 5c), with the former rating $28.1 \%$ and the latter $23.4 \%$.. Vetlink and PMC on the other hand were lowly used.

Table 3 showed that most commercial poultry farms in Imo State are small-scale $(40.4 \%)$ while middle and large scale ones averaged 30.8 and $28.9 \%$ respectively. This is similar to the reports of Etuk et al (2004) for nearby Akwa Ibom state. Table 4a showed that $68(61.82 \%)$ of the 110 agro-livestock practitioners interviewed were combining the poultry business with other sources of livelihood. Table $4 \mathrm{~b}$ further revealed that $30.0 \%$ of these practitioners were involved in one form of crop production or the other, while another 30.0 and $19.1 \%$ were combining their practice with teaching and civil service works respectively. Again, table 4c highlighted the different types of crops produced by these poultry practitioners. Those involved in tubers and root crop productions were $32.4 \%$ each, while vegetable producers rated $29.7 \%$. These data tend to suggest that mixed farming especially of livestock and crops and integrated systems are common practices in the study area and has the advantage of maximizing resource utilization (Tewe, 1995).

\section{Marketing of poultry products}

Table 5a showed that $82.9 \%$ of the farmers sell their poultry products unprocessed. This is probably due to customers demand for life chicken/turkey in the state. Gueye (2002) stated that birds are usually sold alive in Africa and are killed when needed according to religious customs practiced in the area. Table $5 \mathrm{~b}$ revealed that a higher proportion of poultry farmers in Imo state sell their products both by retails and wholesales $(41.9 \%)$, while few of them sell by retail only $(20.9 \%)$. This probably creates profitable market for products sales. The popular form of packaging 
eggs involves egg holders or trays (usually 30 eggs per tray) made of paperboard or plastic. Eggs from farms are sold in crates, either in wholesale or relating. Prices of eggs depend on the size (small, large and medium). Ubosi (2000) reported that consumers would always prefer large and medium sized eggs to small sized ones. Another study by Yannakopoulos et al (1994) in Greece showed that $61.3 \%$ of consumers prefer normal sized eggs (medium) while $36.8 \%$ prefer the large ones. A good proportion of the poultry products (43.3\%) are sold in the urban areas (table $5 \mathrm{~b}$ ), while only $20.0 \%$ are sold in rural areas. This is attributed both to the high population density and higher income level urban dwellers.

\section{Poultry drugs distribution}

Table 6 a showed that $79.32 \%$ of poultry drugs sellers in Imo State are not qualified to retail livestock drugs. Okoli et al, (2002) reported that in Nigeria, any veterinary pharmaceutical could be purchased without prescription. In south eastern Nigeria in particular, hawkers, small traders and illiterate market women are known to be involved in the retailing of veterinary drugs especially poultry medicines. Table $6 \mathrm{~b}$ showed that a higher percentage of the respondents indicated that they consult with veterinary doctors before administering drugs in their farms. Earlier studies by Okoli et al (2002) have however shown that self-medication is rampant in the state. Reasons given for self-medication included, good experience, don't want to spend extra money on medication and lack of veterinary services at the reach of the farmers as highlighted in table 6c. This again is in agreement with the observations of Okoli et al (2002) that self-medication among poultry farmers may be because of unavailability of veterinary services and the extra cost of veterinary services. In deed in many African countries including Nigeria, the number of well-trained animal health personnel is well below the recommended ratio of 20,000 veterinary livestock unit (VLU) per veterinarian (Sandford, 1983; Umali et al, 1994).

In table $7 \mathrm{a}$, antibiotics $(23.9 \%)$, coccidiostat $(23.1 \%)$, vitamins $(17.4 \%)$ and vaccines (14.1\%) were shown to be the most highly sort poultry medicinal products in the state. More soluble poultry drugs are sold probably because more skill is required to administer injectable drugs. Similarly, farmers utilization of antibiotics (42.0\%) was highest, followed by coccidiostat $(34.0 \%)$ and the vaccines $(24.0 \%)$ (Table $7 \mathrm{~b})$. This probably indicates that bacterial infections are the more common disease problems of poultry in the state (Okoli et al, 2002).

\section{Constraints and solutions}

Table 8a showed the different factors that affect poultry business enterprises in Imo state. Practitioners indicated high cost of livestock inputs as the highest factor (31.25\%), followed by lack of adequate finance (26.6\%) and then disease and death of livestock (17.20\%). It has been observed that the performance of livestock in Nigeria usually depends on the quantity and quality of feeds (Ukachukwu and Anugwa, 1995). This high cost of feed is mainly due to the scarcity of feeds ingredients, which results from the competitive demand on them by both humans and livestock. Importation of feed raw material is banned in Nigeria and local production of these products is low (Tewe, 1995). Indeed, of all livestock technologies, none has received attention and interest of animal scientists as the identification and utilization of non-conventional feed (NCF) raw materials for the feeding of poultry (Babatunde, 1998). Similarly, several efforts have been made to disseminate information on NCF to farmers (Dafwang et al, 1996).

Table $8 \mathrm{~b}$ on the other hand highlighted the expectations of practitioners from production scientists. In order of priority, these included, researching for cheaper sources of raw materials (30.77\%), visiting farms for advice (23.08\%) and producing animals with higher feed efficiency. Similarly, table 8c revealed that practitioners ranked financial support in forms of soft loans, credits and subsidies $(58.33 \%)$, as their highest expectation from government, followed by the checking of the soaring cost of livestock inputs $(26.3 \%)$. The present findings are in agreement with previous reports and policy statements on the enhancement of agricultural activities in 
Nigeria.

\section{CONCLUSION}

The present study has shown that most commercial poultry operations in the state are small scaled, while poultry drugs such as antibiotics and coccidiostats are being miss-used by many poultry farmers in the state. Inadequate finance and high cost of livestock inputs were found to be major constraints of the business.

\section{REFERENCES}

Adu, I. F., Aina, A. B. and Okeleye, K. A. (1996). On farm establishment of productivity of Gmelina and Gliricidia as browse for goats. Nigerian Journal of Animal Production, 23 (1): 47 - 52.

Babatunde, G. M. (1998). The Presidential Task force on alternative Feed Resources: Challenges and way forward, Nigerian Society of Animal Production Newsletter, 17(2): 4.

Dafwang, 1. 1., Ikani, I. E. and Adeshinwa, A. O. K. (1996). Ration formulation for poultry and pigs using non-conventional feedstuffs. A Training manual. Zaria: NAERLS/ABU

Etuk, E. B., Okoli, I. C. and Uko, M. U. (2004). Prevalence and management issues associated with poultry coccidiosis in Abak agricultural zone of Akwa Ibom state, Nigeria. International Journal of Poultry Science, 3 (2): 135 - 139.

FAO, (2000). Food and Agricultural Organization of the United Nation, Rome. Quarterly bulletin of statistics, Volume 1.

Gueye, E. F. (2002). Family poultry research and development in low-income food-deficit countries: Approaches and Prospects. Outlook on Agriculture, 31 (1): 13 - 21.

Meremikwu, V. N. (2001). The Performance of starter broilers under subsistence free-range system of production. MSc. Thesis, Federal University of Technology Owerri Nigeria.

Oluyemi, J. A., Roberts, R. A. (1979). Poultry production in wet climates, $2^{\text {nd }}$

Edition. London: Macmillan Press,

Okoli, I. C. (2004). Aerial pollutant gases and temperature levels in poultry housing designs in selected poultry farms in Imo state, Nigeria. In U. C. Malu and F. Gottwald (eds.) Studies of sustainable agriculture and animal science in sub-Saharan Africa. Peter Lang, Frankfurt. Pp. 143 $-151$.

Okoli, I. C., Nwosu C. I., Okoli G. C, Okeudo N. J and Ibekwe V. (2002). Drug management of anti-microbial resistance in avian bacterial pathogen in Nigeria. Int. J. Environ. Health Hum. Dev, 3 (1): 39 - 48.

Okoli, I. C., Anyaegbunam, C. N. Etuk, E. B, Uchegbu, M. C., and Udedibie, A. B. I. (2004). Socio-economic characteristics of poultry business entrepreneurs in Imo State, Nigeria. Journal of Agriculture and social research, 4 (2)

Sandford, S. (1983). Management of pastoral development in the third world. New York.: John Wiley and Sons

Smith, J. D. (1990). Introduction to animal parasitology. London: Hodder and Stoughton

Tewe, O. O. (1995). Sustainability and development, Paradigms for Nigeria's livestock industry. Inaugural lecture, University of Ibadan. Ibadan: University Of Ibadan Press.

Ubosi C O 2000 Poultry production in the livestock industry in Nigeria. A paper presented at the Avian Symposium, $4^{\text {th }}$ April 2000, Maiduguri, Nigeria.

Ukachukwu, S. N. and Anugwa, F. O. I. (1995). Bio-economics of feeding raw or heat treated soybean to broilers. Nigeria Journal of Animal production, 22 (2): $137-140$.

Umali, D. L., Feder, G. and de Haan, C. (1994). Animal health services. Finding the balance between public and private delivery. The World Bank Research Observer, 9 (1): 71 - 96 .

Yannakopoulos, A. L., Batzios, C. A. and Tserveni Gouis, A. S. (1994). A pilot study on consumer attitude towards egg requests. Proceedings of the $9^{\text {th }}$ European Conference, Glasgow, 
UK, August 7-12-pp. 397-398.

Table 1: Types and frequency of practice of the different poultry business enterprises in Imo State

\begin{tabular}{llll}
\hline Poultry business enterprise & Frequency & Percentage \\
\hline 1 & Feed raw materials & 23 & 7.44 \\
2 & Feed milling & 6 & 1.94 \\
3 & Commercial feeds retailing & 56 & 18.12 \\
4 & Turkey farming & 17 & 5.50 \\
5 & Hatchery operation & 7 & 2.27 \\
6 & Egg Production & 48 & 15.53 \\
7 & Poultry equipment & 21 & 6.80 \\
8 & Broiler Production & 47 & 15.21 \\
9 & Drug merchandise & 29 & 9.39 \\
10 & Brood and sell & 28 & 9.06 \\
\hline & Total & $\mathbf{3 0 9}$ & $\mathbf{1 0 0}$ \\
\hline
\end{tabular}

Table 2: Distribution and frequency of utilization of poultry feed brands sold in Imo State (a) Type of feed used by farmers

\begin{tabular}{lll}
\hline Type of feed & Frequency & Percentage \\
\hline Commercial & 35 & 55.56 \\
Home made & 12 & 19.05 \\
Commercial \& Home made & 16 & 15.4 \\
Total & $\mathbf{6 3}$ & $\mathbf{1 0 0 . 0 0}$ \\
(b) Commercial brands of poultry feed sold & \\
\hline Guinea & 7 & 24.1 \\
Zion & 4 & 13.8 \\
Top & 5 & 17.2 \\
Vital & 5 & 17.2 \\
Vetlink & 1 & 3.5 \\
PMC & 1 & 3.5 \\
Livestock & 1 & 3.5 \\
Sanders & 5 & 17.2 \\
Total & $\mathbf{2 9}$ & $\mathbf{1 0 0}$ \\
(C) Commercial feed brands used by farmers & \\
Guinea & 18 & 28.1 \\
Zion & 12 & 18.8 \\
Top & 15 & 23.4 \\
Vital & 12 & 18.8 \\
Vetlink & 2 & 3.1 \\
Sanders & 4 & 6.3 \\
PMC & 1 & 1.6 \\
Total & $\mathbf{6 4}$ & $\mathbf{1 0 0 . 0 0}$ \\
\hline
\end{tabular}


Table 3: Operational size distribution of poultry farms in Imo state

\begin{tabular}{llll}
\hline Number of birds & Frequency & Percentage & Class \\
\hline Below 500 & 21 & 40.38 & Small scale \\
$500-1000$ & 16 & 30.77 & Middle scale \\
Above 1000 & 15 & 28.85 & Large scale \\
Total & $\mathbf{5 2}$ & $\mathbf{1 0 0 . 0 0}$ & \\
\hline
\end{tabular}

Table 4: Frequency of combination of with other Sources of Livelihood with poultry business

(a) Frequency of combination

\begin{tabular}{lll}
\hline Parameters & Frequency & Percentage \\
\hline Poultry business only & 42 & 38.18 \\
Combines poetry business with others & 68 & 61.82 \\
Total & $\mathbf{1 1 0}$ & $\mathbf{1 0 0 . 0 0}$ \\
(b) Types of businesses frequently combined with poultry business & \\
Source of Livelihood & Frequency & Percentage \\
Crop Production & 33 & 30.00 \\
Contractor & 1 & 0.91 \\
Commerce/Trading & 9 & 8.18 \\
Computer Services & 1 & 0.91 \\
Civil Services & 21 & 19.10 \\
Teaching/Lecturing & 34 & 30.90 \\
Nursing & 4 & 3.64 \\
Schooling & 7 & 6.36 \\
Total & $\mathbf{1 1 0}$ & $\mathbf{1 0 0 . 0 0}$ \\
(c) Type of crop produced & & \\
Vegetables & 22 & 29.73 \\
Plantation & 2 & 2.7 \\
Tubers & 24 & 32.43 \\
Pineapple & 2 & 2.7 \\
Roots & 24 & 32.43 \\
Total & $\mathbf{7 4}$ & $\mathbf{1 0 0 . 0 0}$ \\
\hline
\end{tabular}

Table 5: Processing, marketing method and distribution range of poultry products producers in Imo state

(a) Processing

\begin{tabular}{lll}
\hline & Frequency & Percentage \\
\hline Process & 8 & 17.02 \\
Not process & 39 & 82.98 \\
Total & 47 & 100.00 \\
(b) Method & & \\
Whole sale & 16 & 37.21 \\
Retaining & 9 & 20.9 \\
Both & 18 & 41.86 \\
Total & $\mathbf{4 3}$ & $\mathbf{1 0 0 . 0 0}$ \\
(c) Distribution range & & \\
Urban & 26 & 43.33 \\
Rural & 12 & 20.00 \\
Both & 22 & 36.67 \\
Total & $\mathbf{6 0}$ & $\mathbf{1 0 0 . 0 0}$ \\
\hline
\end{tabular}


Table 6: Academic qualifications of drug sellers, prescription patterns and factors influencing prescription of poultry drugs in Imo state

\begin{tabular}{|l|l|l|}
\hline Qualification & Frequency & Percentage \\
\hline Auxiliary Veterinarian & 3 & 10.34 \\
\hline Veterinary Doctors & 3 & 10.34 \\
\hline Others & 23 & 79.32 \\
\hline Total & $\mathbf{2 9}$ & $\mathbf{1 0 0 . 0 0}$ \\
\hline
\end{tabular}

\section{(b) Prescription Pattern}

\begin{tabular}{|l|l|l|}
\hline Prescription & Frequency & Percentage \\
\hline Yes & 11 & 52.38 \\
\hline No & 5 & 17.24 \\
\hline Sometimes & 13 & 44.83 \\
\hline Total & $\mathbf{2 9}$ & $\mathbf{1 0 0 . 0 0}$ \\
\hline
\end{tabular}

(c) Factors Influencing Prescription pattern

\begin{tabular}{|l|l|l|}
\hline Factors & Frequency & Percentage \\
\hline Lack of vet. Doctors & 3 & 11.54 \\
\hline Good experience & 18 & 69.23 \\
\hline Cost of prescription & 5 & 19.23 \\
\hline Total & $\mathbf{2 6}$ & $\mathbf{1 0 0 . 0 0}$ \\
\hline
\end{tabular}

Table 7 Poultry drugs sales volume and farmer drugs utilization characteristics in Imo state (a) Animal drugs sold

\begin{tabular}{|l|l|l|}
\hline Drugs sold & Frequency & Percentage \\
\hline Antibiotics & 29 & 23.97 \\
\hline Vitamins (soluble) & 21 & 17.4 \\
\hline Coccidiostats (soluble) & 28 & 23.1 \\
\hline Vaccine & 17 & 14.05 \\
\hline Growth Promoter & 12 & 9.92 \\
\hline Premix & 8 & 6.60 \\
\hline Injectables (Antibiotics, vitamins etc) & 6 & 4.96 \\
\hline Total & $\mathbf{1 2 1}$ & $\mathbf{1 0 0 . 0 0}$ \\
\hline
\end{tabular}

(b) Farmers drug utilization pattern

\begin{tabular}{|l|l|l|}
\hline Drugs sold & Frequency & Percentage \\
\hline Antibiotics & 21 & 42 \\
\hline Vitamins & - & \\
\hline Coccidiostats & 17 & 34 \\
\hline Vaccine & 12 & 24 \\
\hline Growth Promoter & - & - \\
\hline Premix & - & - \\
\hline Injectables & - & - \\
\hline Total & $\mathbf{5 0}$ & $\mathbf{1 0 0}$ \\
\hline
\end{tabular}


Table 8: Factor affecting poultry business enterprises in Imo state

\begin{tabular}{|l|l|l|}
\hline (a) Factors & Frequency & Percentage \\
\hline 1. Disease and death of livestock & 11 & 17.2 \\
\hline 2. High cost of livestock inputs & 20 & 31.25 \\
\hline 3. Inadequate supply of chicks & 3 & 4.69 \\
\hline 4. Poor egg production and low chicks quality & 4 & 6.25 \\
\hline 5. High cost of transportation of inputs & 7 & 10.94 \\
\hline 6. Poor hatchability of eggs & 2 & 3.13 \\
\hline 7. Lack of adequate finance & 17 & 26.6 \\
\hline (b) Practitioners expectations from veterinary scientists & \\
\hline Expectation & Frequency & Percentage \\
\hline 1. Research for cheaper source of raw material & 8 & 30.77 \\
\hline 2. Produce animals with high feed efficiency & 3 & 11.54 \\
\hline 3.to be involved in livestock enterprise & 3 & 1.54 \\
\hline 4. Visiting farms for advice & 3 & 23.08 \\
\hline 5. Helping farmer get loans from government & 6 & 11.54 \\
\hline 6. Improve breeds of chicks & 3 & 11.54 \\
\hline (c) Practitioners expectations from government & 3 & \\
\hline Expectation & Frequency & Percentage \\
\hline 1. Provision of quality local drugs & 1 & 1.39 \\
\hline 2. Financial support (soft loans and subsidies) & 42 & 58.33 \\
\hline 3. Check the soaring cost of inputs & 19 & 26.39 \\
\hline 4. Importation of better producing breeds & 6 & 8.33 \\
\hline 5. Defining land ownership to favor farmers & 1 & 1.39 \\
\hline 6. Establishing poultry research centers & 3 & 4.17 \\
\hline Total & $\mathbf{7 2}$ & $\mathbf{1 0 0}$ \\
\hline & \multicolumn{2}{|l|}{} \\
\hline
\end{tabular}

